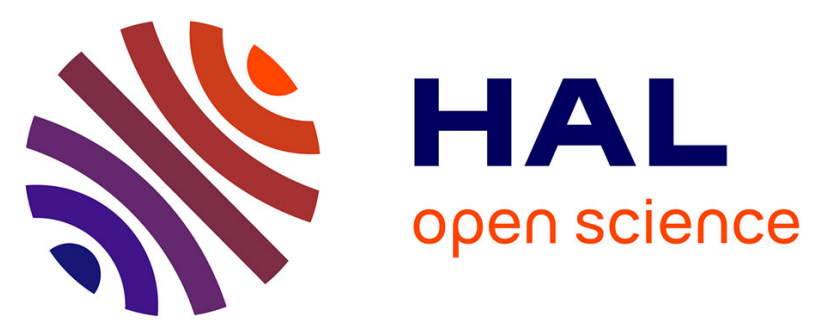

\title{
Comparative study of humic acids of the mound of a wood-feeding termite and of the litter directly below in the Amazon river delta
}

\author{
Jean-François Richard, Ghita Ait Baddi, Carlos Costa, Maritxu Guiresse, \\ Michel Kaemmerer, Mohamed Hafidi, Jean-Claude Revel
}

\section{To cite this version:}

Jean-François Richard, Ghita Ait Baddi, Carlos Costa, Maritxu Guiresse, Michel Kaemmerer, et al.. Comparative study of humic acids of the mound of a wood-feeding termite and of the litter directly below in the Amazon river delta. Chemistry and Ecology, 2006, vol. 22 ( $\mathrm{n}^{\circ} 3$ ), pp. 201-209. 10.1080/02757540600658807 . hal-01517382

\section{HAL Id: hal-01517382 \\ https://hal.science/hal-01517382}

Submitted on 3 May 2017

HAL is a multi-disciplinary open access archive for the deposit and dissemination of scientific research documents, whether they are published or not. The documents may come from teaching and research institutions in France or abroad, or from public or private research centers.
L'archive ouverte pluridisciplinaire HAL, est destinée au dépôt et à la diffusion de documents scientifiques de niveau recherche, publiés ou non, émanant des établissements d'enseignement et de recherche français ou étrangers, des laboratoires publics ou privés. 


\section{Open Archive TOULOUSE Archive Ouverte (OATAO)}

OATAO is an open access repository that collects the work of Toulouse researchers and makes it freely available over the web where possible.

This is an author-deposited version published in : http://oatao.univ-toulouse.fr/ Eprints ID : 17585

To link to this article : DOI:10.1080/02757540600658807

URL : http://dx.doi.org/10.1080/02757540600658807

To cite this version : Richard, Jean-François and Ait Baddi, Ghita and Costa, Carlos and Guiresse, Maritxu and Kaemmerer, Michel and Hafidi, Mohamed and Revel, Jean-Claude Comparative study of humic acids of the mound of a wood-feeding termite and of the litter directly below in the Amazon river delta. (2006) Chemistry and Ecology, vol. 22 (n 3). pp. 201-209. ISSN 0275-7540

Any correspondence concerning this service should be sent to the repository administrator: staff-oatao@listes-diff.inp-toulouse.fr 


\title{
Comparative study of humic acids of the mound of a wood-feeding termite and of the litter directly below in the Amazon river delta
}

\author{
J. F. RICHARD $\dagger$, G. AIT BADDI $\ddagger$, C. COSTA $\S$, M. GUIRESSE $\dagger$, M. KAEMMERER $\dagger$, \\ M. HAFIDI* $*$ and J. C. REVEL $\dagger$ \\ †Agronomy Environment Ecotoxicology Laboratory, ENSAT INP-BP 107, F 31326 Castanet \\ Tolosan cedex, France \\ $\$$ Plant Ecology and Environment Laboratory, Faculty of Science Semlalia, \\ Cadi Ayad University, BP 2390, Marrakech, Morocco \\ $\S$ Department of Plant Biology, Para Science Faculty, Avenue Tancredo \\ neves s/n, Terra Firme/Pa66077-530 Bélem, Brazil
}

\begin{abstract}
In order to determine the role of termites in the recycling of organic matter and in humification processes, organic matter from the mound of a wood-feeding termite (Nasutitermes sp.) and from the litter directly below has been studied in secondary forest on the campus of Belem University, in Brazil. The carbon content was slightly lower in the litter (just beneath the mound) than in the mound, but nitrogen was much more abundant in the mound. As a consequence, the $\mathrm{C} / \mathrm{N}$ ratio of fragmented litter total organic matter is very high, which shows that the humification process is not complete. Therefore, plant debris seemed to be more degraded in the mound than in the litter, indicating a humification gradient from mound to litter. Humic acid extracted from the mound and from the litter was compared by using elemental, E4/E6 ratio, spectroscopic (FTIR) analyses, and Sephadex gel chromatography. First, humic acids were more abundant in the mound than in the litter, showing that humification processes were more advanced in the mound than in the litter. Gel-permeation chromatography showed that the humic acids of the mound contained more low-molecular-weight fractions than those of the litter. In addition, the results of infrared spectra, E4/E6 ratio and elemental composition can confirm the fulvic character of mound material and the humic character of litter material. Therefore, the plant debris seems to follow two different humification pathways in the two environments, as long as the mound is alive.
\end{abstract}

Keywords: Wood-feeding termites; Mound; Litter; Humic acids

\section{Introduction}

The annual litter fall, in the tropical lowland forests, ranges between 6 and $12 \mathrm{t} \mathrm{ha}^{-1}$ [1]. The major part of the total litter fall is constituted by leaves, thus providing an important nutrient

\footnotetext{
*Corresponding author. Email: hafidi@ycam.ac.ma
} 
pool. Leaf-litter breakdown is a key component in nutrient cycling in tropical forests. Decomposition processes are regulated by a number of abiotic and biotic factors [1]. The biotic factors comprise a wide range of communities, including bacteria, fungi, and invertebrates [2]. In tropical forests, the biological activity of decomposers is concentrated in the litter and topsoil [3]. Termites are one of these macroinvertebrates which are eusocial insects and whose colonies are among the most impressive animal phenomena in the world [4]. Termites are very important ecological players, especially in tropical ecosystems, having been described as 'ecosystem engineers' due to their important role in providing soil ecosystem services [5]. These services include: distribution, protection, and stabilization of organic matter, increasing microsite heterogeneity, the genesis of soil microaggregates and porosity, the release of immobilized $\mathrm{N}$ and $\mathrm{P}$, the improvement of drainage and aeration, and an increase in exchangeable cations and humification [6,7]. Indeed, Brauman [8] reported that in the termitosphere, the ingestion of soil organic carbon and its transformation during digestion results in more stable soil organic carbon forms. In tropical rainforests, their consumption of plant material can reach 6 or $7 \mathrm{t} \mathrm{y}^{-1} \mathrm{ha}^{-1}$, which can account for about $50 \%$ of the biomass [9]. However, in the desert of Arizona, with about 10 different species of termites, this percentage can reach $92 \%$ of the dead wood produced in a year [10]. Termites' functions are due essentially to the symbiotic relationship between termites and the micro-organisms inhabiting their gut, which enables them to live exclusively on lignocellulosic materials [11]. In this respect, Brauman [8] and Brune [12] attributed the unusual ability of termites to thrive on lignocellulosic plant materials (sound or decaying wood, grass, animal dung, or plant litter) at various stages of humification to their enlarged hindguts. According to the same authors, symbiotic gut microflora in termites' hindguts depolymerize cellulose, hemicelluloses and lignins. Recently, Schmitt-Wagner [13] demonstrated by employing microsensor techniques that the metabolic activity of the gut microbiota maintains steep oxygen and hydrogen gradients within the gut lumen. Despite the significant advances made concerning wood-feeding termites, little is known about the mechanisms involved in their digestion. Moreover, our knowledge is still limited, mainly concerning the way that humic compounds can be derived from the activities. In the objective to follow humification processes, the following study compares the organic matter of the xylophagous Nasutitermes sp. termite mounds $2 \mathrm{~m}$ above soil level in a tree with those of the litter directly below by physico-chemical analyses in a secondary forest on the campus of the University of Belem (Brazil). The process of humification is also followed by studying humic acids extracted from mounds with those from litter by elemental, spectroscopic (FTIR) analyses and by Sephadex ${ }^{\circledR}$ G25F gel chromatography.

\section{Materials and methods}

\subsection{Study site}

The studied area is situated in a secondary forest study plot on the campus of the University of Belem (Brazil). The xylophagous Nasutitermes sp. builds mounds on trees and constructs shelter tubes on the surface of the bark. A fragment of active mound was taken. Samples were taken from the soil directly beneath the mounds. According to Vieira and Dos Santos [15], this soil is an 'amarelo latossolo' and a xanthic ferralsol (FrX), according to FAO-UNESCO [16]. Under a 1-2-cm layer of only slightly degraded litter of leaves and twigs [17], thinly fragmented and already humified litter can be found. The debris in the litter is small, dark brown, and difficult to identify. Under the litter, there is a mineral-organic horizon. Its gray colour increases with depth ( 5 Y $3 / 2$ on top to 5 Y $5 / 2$ at a depth of $20 \mathrm{~cm}$ ). This horizon is 
clayey and has a crumbly structure and high compaction porosity. The comparison was made between the material of the mound (M) and of the thinly fragmented litter (OF) directly below.

\subsection{Analytical methods}

2.2.1 Physico-chemical analyses. The samples of termites' mounds and of litter were airdried, crushed, and dry-sieved $<0.5 \mathrm{~mm}$. The proportion of mineral matter was assessed by calcination. Total N was determined following Kjeldhal digestion [18] and organic carbon according to Walkey-Black's method as described by Nelson and Sommers [19].

2.2.2 Extraction of the humic substances. After decalcification by $0.1 \mathrm{M} \mathrm{HCl}$, then lipids delete with petroleum ether-ethyl acetate mixture, humic acids were extracted from termites' mounds and from litter using classic, solubility-based fractionation [20,21]. Treated with $0.1 \mathrm{M}$ $\mathrm{NaOH}$ at room temperature, the samples were shaken for $1 \mathrm{~h}$ and then centrifuged $(3000 \mathrm{~g})$. This operation was repeated until the supernatant obtained was clear. The separation of fulvic acids from humic acids was achieved by acidification with $\mathrm{H}_{2} \mathrm{SO}_{4}$ of the supernatant until $\mathrm{pH}$ 1.5. The two fractions were separated by centrifugation when the humic acids precipitated.

2.2.3 E4/E6 ratio. The precipitated humic acids of termites' mounds and of litter are characterized by their E4/E6 ratio (absorbance at $472 \mathrm{~nm}$ over absorbance at $665 \mathrm{~nm}$ ).

2.2.4 Gel permeation chromatography. The humic acid samples of termites' mounds and of litter were dissolved in $0.1 \mathrm{M} \mathrm{NaOH}$ and injected onto a gel-permeation chromatography column (length, $18 \mathrm{~cm}$; diameter, $4.9 \mathrm{~cm}$ ) filled with G25F Sephadex ${ }^{\circledR}$ dextran gel (Pharmacia). Distilled water was used as eluent with a flow of $30 \mathrm{ml} \mathrm{h}^{-1}$ (samples of $1 \mathrm{ml}$ were equilibrated at $\mathrm{pH} 7.1$ with $\mathrm{HNO}_{3}$ ) and the exclusion volume was $5000 \mathrm{D}$. The results are given for absorbance with regard to $K_{\text {av }}=$ (elution volume-exclusion volume)/(total resin volume - exclusion volume) according to Determann [22].

2.2.5 Elemental analysis. The humic acids of termites' mounds and of litter were also dialysed through a cellulose ester membrane with an end-point threshold of $1000 \mathrm{D}$ and then freeze-dried to analyse their elemental composition. Carbon, hydrogen, and nitrogen were determined using a Fisson E. A 1.04 carbograph auto-analyser, and the oxygen content was calculated as the difference from 100 .

2.2.6 Spectroscopy Fourier-Transform InfraRed (FTIR). Infrared spectra (1 mg of humic acids in $300 \mathrm{mg}$ of $\mathrm{KBr}$ ) were obtained with a Perkin Elmer 1600 FTIR. The total acidity of humic acids was measured following a protocol described by Schnitzer [23].

\section{Results and discussion}

The results of the analyses on humified litter and mound are presented in table 1 . The carbon content and $\mathrm{C} / \mathrm{N}$ ratio of the mound were very close to the results of Amelung et al. [24]. The dry matter in the termite mound sample and in the litter had the same level of carbon, while the level of nitrogen in the mound was double that of the litter (table 1). The same results were 
Table 1. Composition of mound and surrounding crude humified litter.

\begin{tabular}{lcccccr}
\hline & $\mathrm{H}_{2} \mathrm{O} \mathrm{pH}$ & $\mathrm{KCl} \mathrm{pH}$ & $\mathrm{MM}(\%)$ & $\mathrm{C}$ & $\mathrm{N}$ & $\mathrm{C} / \mathrm{N}$ \\
\hline Litter & 3.70 & 3.40 & 7.00 & 46.60 & 0.40 & 116.60 \\
Mound & 5.60 & 5.10 & 3.50 & 48.80 & 1.05 & 46.50 \\
\hline
\end{tabular}

Note: MM: mineral matter; $\mathrm{C}$ and $\mathrm{N}$ are expressed as percentage dry matter.

found by Eggleton and Tayasu [25]. Organic compounds ( $\mathrm{C}$ and particularly $\mathrm{N}$ ) were more abundant in the termite mound than in surrounding soils as reported by Lopez-Hernandez [26]. Tayasu [27] explained that the extremely alkaline conditions present in termite guts may allow the decomposition of recalcitrant materials. In this respect, the very high $\mathrm{C} / \mathrm{N}$ ratio of fragmented litter total organic matter in the present study shows that the humification process is not complete. As there is no fully humified litter, this means that the biomass covering the soil is quickly mineralized, and only a very small part is humified and incorporated into the mineral horizon. This is why the extraction of litter humic acids was low. On the other hand, this low quantity might be due to the lignocellulosic composition of litter after alkaline extraction, mainly plant and microbial protein precipitated by plant phenols.

In litter, the $\mathrm{C} / \mathrm{N}$ ratio of total organic matter was very different from that of extracted humic acids (116.6 vs. 46.34). By contrast, the $\mathrm{C} / \mathrm{N}$ ratio of mound total organic matter and extracted humic acids varied only slightly (46.5 against 53.2). A high proportion of the organic matter (expressed as carbon) was in the form of humic acid, so mound matter appears to be far more humified and homogeneous.

The results concerning the characterization of humic acids extracted from mound and thinly fragmented litter by elemental analysis and $\mathrm{E}_{4} / \mathrm{E}_{6}$, are presented in table 2 . The extraction yield was slightly higher for mound humic acids. The latter contained less carbon and nitrogen but more oxygen than litter humic acids. As a consequence, the $\mathrm{C} / \mathrm{N}$ ratio for the mound humic acids was higher. Moreover, the $\mathrm{C} / \mathrm{H}$ ratio was slightly higher for mound humic acids than for litter humic acids. The higher value of $\mathrm{C} / \mathrm{H}$ ratio indicates, according to Senesi et al. [28], the high degree of condensation of these acids compared with the litter humic acids. Stevenson [29] also reports that the higher the $\mathrm{C} / \mathrm{H}$ ratio, the higher the degree of unsaturation of humic materials. Other authors [30] have explained that the higher value of the $\mathrm{C} / \mathrm{H}$ ratio in woody composts is due mainly to the formation of unsaturated bonds, suggesting the start of a condensation and/or polymerization process. Differences can also be observed in the chemical analysis, which shows that mound humic acids contain more oxygen. As a consequence, the $\mathrm{O} / \mathrm{C}$ ratio is also higher for mound humic acids than for litter humic acids. Garcia et al. [31] have explained this trend for organic wastes by the existence of oxidation processes characteristic of humification. Likewise, Kakezawa et al. [30] attributed the increase in this

Table 2. Mound and litter humic acids analyses.

\begin{tabular}{|c|c|c|c|c|c|c|c|c|c|c|c|}
\hline & \multirow{2}{*}{$\begin{array}{l}\text { Total } \\
\mathrm{C} \%{ }^{\mathrm{a}}\end{array}$} & \multirow[b]{2}{*}{$\mathrm{C} \%$} & \multirow[b]{2}{*}{$\mathrm{N} \%$} & \multirow[b]{2}{*}{$\mathrm{H} \%$} & \multirow[b]{2}{*}{$\mathrm{O} \%$} & \multirow[b]{2}{*}{ Ashes \% } & \multicolumn{3}{|c|}{ Atomic ratios } & \multirow[b]{2}{*}{ E4/E6 } & \multirow{2}{*}{$\begin{array}{l}\text { Total acidity } \\
\left(\mathrm{mmol} \mathrm{g}^{-1}\right)\end{array}$} \\
\hline & & & & & & & $\mathrm{C} / \mathrm{N}$ & $\mathrm{C} / \mathrm{H}$ & $\mathrm{C} / \mathrm{O}$ & & \\
\hline $\begin{array}{r}\text { Litter } \\
\text { HA }\end{array}$ & 20.50 & 31.38 & 0.79 & 3.40 & 41.55 & 22.88 & 46.34 & 0.77 & 1.00 & 8.10 & 3.88 \\
\hline $\begin{array}{c}\text { Mound } \\
\text { HA }\end{array}$ & 30.60 & 22.34 & 0.49 & 2.24 & 54.62 & 20.31 & 53.20 & 0.83 & 0.55 & 10.60 & 1.48 \\
\hline
\end{tabular}


ratio in woody composts to oxidation of the phenolic compounds and/or the aliphatic chains. Moreover, these authors suggested that introduction of carbohydrate and oxidation of phenolic compounds with methoxyl groups and/or aliphatic side-chains in the humic acid occurs during lignin degradation. The E4/E6 ratio varied only slightly, regardless of the origin of the organic matter. Dick and Burba [32] reported for humic substances that the absorbance ratio E4/E6 is a traditional parameter to estimate their humification degree and/or their molecular size. This ratio was slightly higher for the mound humic acids, indicating that the molecules were less aromatic with carbon mainly located in side chains [33] and a higher level of oxygen. The oxygen was not found under the form of acidic groups, since acidity measurements showed low values.

Humic acids from both litter and mound presented the expected infrared spectra characteristics for humic acids. Common absorption bands can be observed in both spectra (figure 1 and table 3) and are typical for humic compounds [20, 34-37]. However, the presence of some absorption bands is linked to the origin of the humic acids. In the mound humic acids, the presence of absorption bands at $623 \mathrm{~cm}^{-1}$ (aromatic rings) and at 1508 and $1593 \mathrm{~cm}^{-1}$ can be observed. However, peaks at $3620 \mathrm{~cm}^{-1}\left(\mathrm{OH}\right.$ groups), at 1617 and $913 \mathrm{~cm}^{-1}$ (aromatic $\mathrm{C}=\mathrm{C}$ ), at $1034 \mathrm{~cm}^{-1}\left(\mathrm{C}-\mathrm{O}\right.$ of polysaccharides), and between 500 and $700 \mathrm{~cm}^{-1}(\mathrm{CH}$ of polysaccharides) were only observed for litter humic acids. In litter, although lignin was not observed, its degradation products were revealed by absorption bands attributed to $\mathrm{C}=\mathrm{O}$ bonds on phenols $\left(1388 \mathrm{~cm}^{-1}\right)$ or to aromatic $\mathrm{C}=\mathrm{C}\left(1617\right.$ and $\left.913 \mathrm{~cm}^{-1}\right)$. Lin and Dence [38] reported that bands at 1420,1230 , and $1130 \mathrm{~cm}^{-1}$ reflected the presence of products of lignin degradation, in particular, vanillic and syringic acids. By contrast, the polysaccharide content apparently remained high (polysaccharides $\mathrm{C}-\mathrm{O}$ ). Cellulose is therefore thought to degrade more slowly in the litter. On the contrary, in mound humic acid, absorption peaks linked to the presence of native lignin (at 1593 and $1508 \mathrm{~cm}^{-1}$ ) can be observed. Thus, it is apparently not degraded in termites' intestines.
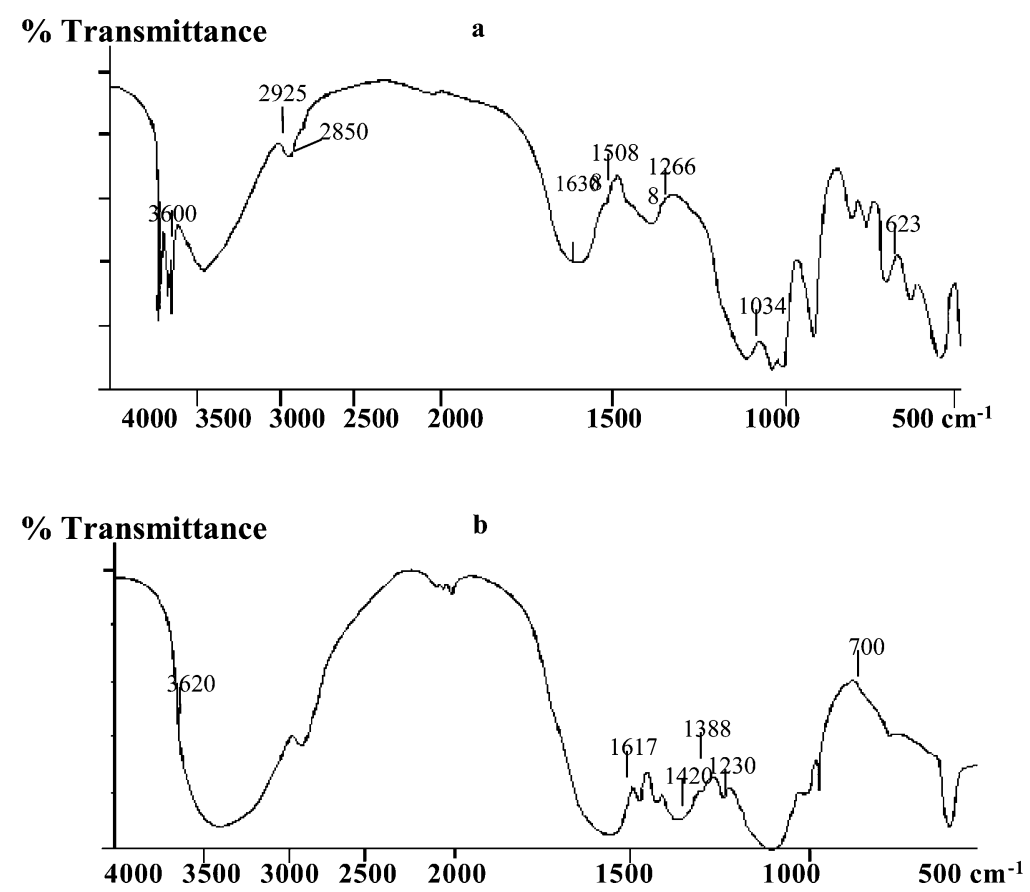

Figure 1. Infrared spectra of (a) mound humic acids and (b) litter humic acids. 
Table 3. Attributions of the infrared peaks of the humic acids extracted from both mound and litter.

\begin{tabular}{|c|c|}
\hline Wavelength & Attribution \\
\hline $3300-3500 \mathrm{~cm}^{-1}$ & $\begin{array}{l}\mathrm{O}-\mathrm{H} \text { vibrations of the hydroxyl groups of phenols, alcohols and } \\
\text { carboxyl functions and } \mathrm{N}-\mathrm{H} \text { vibrations from amides and amines }\end{array}$ \\
\hline $2925-2942 \mathrm{~cm}^{-1}$ & Symmetric $\mathrm{CH}$ stretching in $-\mathrm{CH}_{3}$ and $-\mathrm{CH}_{2}-$ of aliphatic chains \\
\hline $2840 \mathrm{~cm}^{-1}$ & $\begin{array}{l}\text { Asymmetric } \mathrm{CH} \text { stretching in }-\mathrm{CH}_{3} \text { and }-\mathrm{CH}_{2}-\text { of aliphatic } \\
\text { chains }\end{array}$ \\
\hline $1725-1710 \mathrm{~cm}^{-1}$ & $\begin{array}{l}\mathrm{C}=\mathrm{O} \text { stretching in carboxylic acids and/or in carbonyls, ketones, } \\
\text { and aldehydes }\end{array}$ \\
\hline $1654-1640 \mathrm{~cm}^{-1}$ & $\begin{array}{l}\mathrm{C}=\mathrm{O} \text { stretching in quinones and/or in ketonic acids and primary } \\
\text { amides }\end{array}$ \\
\hline $1540-1510 \mathrm{~cm}^{-1}$ & $\begin{array}{l}\text { Aromatic } \mathrm{C}=\mathrm{C} \text { stretching and/or } \mathrm{N}-\mathrm{H} \text { deformation and } \mathrm{C}=\mathrm{N} \\
\text { stretching in secondary amides }\end{array}$ \\
\hline $1460-1440 \mathrm{~cm}^{-1}$ & $\begin{array}{l}\text { Aliphatic } \mathrm{C}-\mathrm{H} \text { deformation of structures such as fatty acids and } \\
\text { waxes occurring in composts }\end{array}$ \\
\hline $1380 \mathrm{~cm}^{-1}$ & $\begin{array}{l}\mathrm{O}-\mathrm{H} \text { deformation, } \mathrm{C}=\mathrm{O} \text { stretching of phenols, anti-symmetric } \\
\mathrm{COO}-\text { stretching and aliphatic } \mathrm{C}-\mathrm{H} \text { deformation }\end{array}$ \\
\hline $1260-1200 \mathrm{~cm}^{-1}$ & $\begin{array}{l}\mathrm{C}-\mathrm{OH} \text { stretching of aromatic groups and } \mathrm{C}-\mathrm{O}-\mathrm{C} \text { stretching of } \\
\text { aryl ethers and phenols }\end{array}$ \\
\hline $1115-1250 \mathrm{~cm}^{-1}$ & Alcohol function vibrations \\
\hline $1010-960 \mathrm{~cm}^{-1}$ & $\mathrm{C}-\mathrm{O}-\mathrm{C}$ stretching of carbohydrates \\
\hline $800-817 \mathrm{~cm}^{-1}$ & $\mathrm{C}-\mathrm{H}$ deformation of substituted aromatic groups \\
\hline
\end{tabular}

Concerning the gel-permeation chromatographs of humic acids from both sources, the elution curves present three peaks corresponding to three different molecular types with a specific molecular mass for each (figure 2). The first exclusion peak (I of $K_{\text {av }}=0$ ) can be observed for molecules with a molecular mass above $5000 \mathrm{D}$. This fraction is considerable for humic acids from both sources. As already noted by Klapper and Brune [21], the first peak was slightly biased towards smaller molecules. The second peak $\left(K_{\mathrm{av}}=0.44\right)$ is also common, whereas the other peaks are specific. The ratio between peak I and the other peaks shows that mound humic acids contain a large number of small molecules as opposed to those extracted from the litter. No significant differences were observed for samples separated on higher-resolution resins (G 75 and G 100). The results obtained on Sephadex ${ }^{\circledR}$ dextran gel

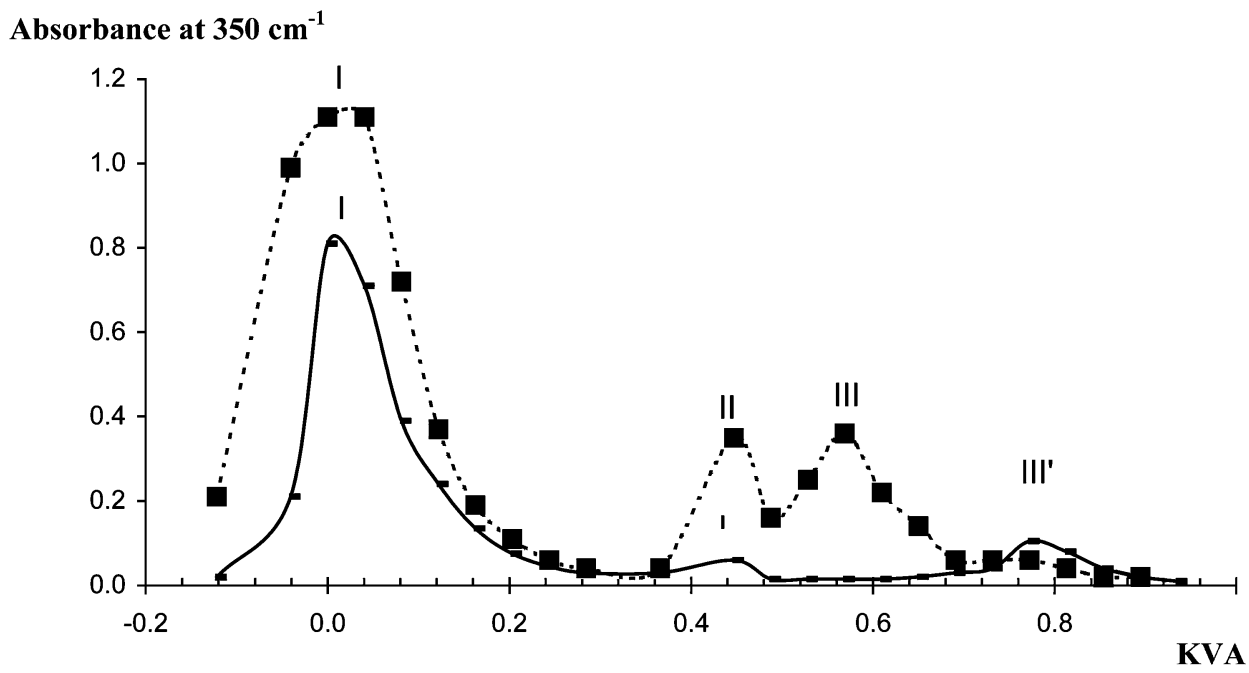

Figure 2. Separation on Sephadex ${ }^{\circledR}$ G25F of a solution of litter humic acids (-) and mound humic acids (-- -). 
indicate a large proportion of small molecules (below $5000 \mathrm{D}$ ) for the mound humic acids. These molecules could be the intermediate compounds of cellulose degradation as described by Kononova [39]. Dick and Burba [32] have studied humic and fulvic acids extracted from two Brazalian soils and reported that fulvic acids were mainly found in the smaller fractions in contrast to the corresponding humic acids whose main fractions were found between 50 and $100 \mathrm{kDa}$ and $>100 \mathrm{kDa}$. This result can confirm the fulvic character of mound material and the humic character of litter.

Overall, the wood-feeding termites derive their nutrition from cellulose in wood. Within the termite's gut are large numbers of bacteria and protozoa. The latter micro-organisms produce enzymes that digest cellulose causing the breakdown of wood particles to simpler compounds that termites can absorb as food [40]. The same results were reported by Nguyen [41], who studied the composition of wood-eating termites gut flora. The study showed that gut micro-organisms are specialized in cellulose digestion, fermentation, methane production, nitrogen fixing, and more. Furthermore, the isolation of pure cultures of spirochete bacteria has permitted their role to be identified [41]. Indeed, these spirochetes catalyse the formation of acetate, a key source of energy for termites. Moreover, spirochetes can also fix nitrogen.

Finally, the tree-inhabiting termites Nasutitermes sp. build their nests with a mixture of wood and stercoraceous materials. The latter are similar to humic substances. However, when comparing the mound humic acids with those of the litter directly beneath, the following was noted:

- In litter, the humic acids originated from lignin, cellulose being only slightly humified.

- In the mound, the humic acids were partly of small molecular mass and mainly derived from cellulose. They could be the precursors of more condensed humic substances.

The conditions in the medium and particularly the relatively acid $\mathrm{pH}$ of the litter should allow the development of micro flora containing more lignivorous fungi. The $\mathrm{pH}$ of faeces along with the known symbionts and termite metabolism is in agreement with cellulose degradation. As Lopez-Hernandez [26] has already emphasized, tree-inhabiting termites (Nasutitermes sp.) consume a large part of the biomass produced, but humification appears to follow a different path in the mound than in the surrounding soil, as long as the mound is alive.

\section{Conclusion}

The organic matter of termite mound is compared with the organic matter of litter directly below by using physico-chemical analyses. The overall results showed that organic compounds were more abundant in the termites' mound than in litter, indicating that there is a humification gradient from mound to litter. The $\mathrm{C} / \mathrm{N}$ ratio of fragmented litter total organic matter is very high, which shows that the humification process is not complete. The litter is not fully humified, indicating that biomass covering the soil is quickly mineralized, and only a very small part is humified and incorporated into the mineral horizon. In order to study the humification process, humic acids extracted from both mound and litter were characterized by elemental, $\mathrm{E}_{4} / \mathrm{E}_{6}$, FTIR analyses and G25 F Sephadex gel chromatography. The results showed that litter humic acids originated from lignin, cellulose being only slightly humified. However, mound humic acids were partly of small molecular mass and mainly derived from cellulose. They could be the precursors of more condensed humic substances. Consequently, wood-feeding termites (Nasutitermes sp.) consume a large part of the biomass produced, but humification seems to follow a different path in the mound and in the litter, as long as the mound is alive. 


\section{Acknowledgements}

The authors thank L. S. Vieira and T. dos Santos, for their contribution in the field for sampling, and P. Winterton (native English speaker), for his helpful criticisms of the English version of the manuscript. This work was funded by the CAPES COFECUB programme.

\section{References}

[1] S.E. Attignon, D. Weibel, T. Lachat, B. Sinsin, P. Nagel, R. Peveling. Leaf litter breakdown in natural and plantation forests of the Lama forest reserve in Benin. Appl. Soil Ecol., 27, 109-124 (2004).

[2] J.D. Knoepp, D.C. Coleman, D.A. Crossley Jr, J.S. Clark. Biological indices of soil quality: an ecosystem case study of their use. Forest Ecol. Manage., 138, 357-368 (2000).

[3] E. Barros, B. Pashanasi, R. Constantino, P. Lavelle. Effect of land-use system on the soil macrofauna in western Brazilian Amazonia. Biol. Fertil. Soil, 35, 338-347 (2002).

[4] D.K. Aanen, P. Eggleton, C.R. Lefêvre, T. Guldberg-Frøslev, S. Rosendahl, J.J. Boomsma. The evolution of fungus-growing termites and their mutualistic fungal symbionts. Proc. Natl. Acad. Sci. USA, 99, 14887-14892 (2002).

[5] P. Eggleton. Termites and trees: a review of recent advances in termite phylogenetics. Ins. Soc., 48, 187-193 (2001).

[6] S.E. Donovan, P. Eggleton, W.E. Dubbin, M. Batchelder, L. Dibog. The effect of a soil-feeding termite, Cubitermes fungifaber (Isoptera: Termitidae) on soil properties: termites may be an important source of soil microhabitat heterogeneity in tropical forests. Pedobiologia, 45, 1-11 (2001).

[7] P. D’Odorico, F. Laio, A. Porporato, I. Rodriguez-Iturbe. Hydrologic controls on soil carbon and nitrogen cycles. II. A case study. Adv. Water Res., 26, 59-70 (2003).

[8] A. Brauman. Effect of gut transit and mound deposit on soil organic matter transformations in the soil feeding termite: a review. Eur. J. Soil Biol., 36, 117-125 (2000).

[9] C. Rouland, A. Brauman, M. Labat, M. Lepage. Nutritional factors affecting methane emission from termites. Chemosphere, 26, 617-622 (1993).

[10] T.G. Myles. The ecological importance of termites and the potential utilization of termites for the decomposition of lignocellulose wastes, paper presented at Proceedings of International Workshop on Termites-Symboint Systems, Kyoto, Japan (1999).

[11] M. Ohkuma, S. Noda, T. Kudo. Phylogenetic diversity of nitrogen fixation genes in the symbiotic microbial community in the gut of diverse termites. Appl. Environ. Microbiol., 65, 4926-4934 (1999).

[12] A. Brune. Termite guts: the world's smallest bioreactors. Trends Biotechnol., 16, 16-21 (1998).

[13] D. Schmitt-Wagner. The intestinal microbiota of soil-feeding termites. Microbial diversity, community structure, and metabolic activities in the highly compartmentalized gut of Cubitermes spp. PhD thesis, Universität Konstanz (2003).

[14] R. Ji, A. Brune. Transformation and mineralization of 14C-labeled cellulose, peptidoglycan, and protein by the soil-feeding termite Cubitermes orthognathus. Biol. Fertil. Soils, 33, 166-174 (2001).

[15] S.L. Vieira, P.C. dos Santos. Amazonia. Sues Solos E Outros Recursos Naturais, p. 416. Agronomica Ceres, São Paulo (1987).

[16] FAO-UNESCO. Soil Map of the World, Revised Legend. ISRIC, Wageningen (1997).

[17] B. Jabiol, A. Brethes, J.F. Ponge, F. Toutain, J.J. Brun. L'humus sous toutes ses formes, p. 64. ENGREF Editeur, Nancy (1995).

[18] J.M. Bremner. Nitrogen-total. In Method of Soil Analysis. Part 3-Chemical Method, J.M. Bigham (Ed. in chief), Soil Science Society of America, Madison, WI (1996).

[19] D.W. Nelson, L.E. Sommers. Total carbon, organic carbon, and organic matter. In Methods of Soil Analysis: Chemical Methods Part 3, D.L. Sparks (Ed.), pp. 961-1010, Soil Science Society of America, American Society of Agronomy, Madison, WI (1996).

[20] F.J. Stevenson. Humus Chemistry, Genesis, Composition, Reaction, p. 443, Wiley Interscience, New York (1982).

[21] A. Kappler, A. Brune. Influence of gut alkalinity and oxygen status on mobilization and size-class distribution of humic acids in the hindgut of soil-feeding termites. Appl. Soil Ecol., 13, 219-229 (1999).

[22] H. Determann. Chromatographie sur gel. Filtration, perméation, tamisage moléculaire, p. 193, Masson et Cie, éditeurs, Paris (1969).

[23] M. Schnitzer. Chemical, spectroscopic and thermal methods for the classification and characterization of humic substances, paper presented at Proceedings of the International Meeting on Humic Substances, pp. 47-58, Nieuwesluis, Pudoc, Wageningen (1972).

[24] W. Amelung, C. Martius, A.G. Bandeira, M.V.B. Garcia, W. Zech. Lignin characteristics and density fractions of termite nests in an Amazonian rainforest-indicators of termites feeding guilds. Soil Biol. Biochem., 34, 367-372 (2002).

[25] P. Eggleton, I. Tayasu. Feeding groups, lifetypes and the global ecology of termites. Ecol. Res., 16, 941-960 (2001)

[26] D. López-Hernández. Nutrient dynamics (C, N and P) in termite mounds of Nasutitermes ephratae from savannas of the Orinoco Llanos (Venezuela). Soil Biol. Biochem., 33, 747-753 (2001). 
[27] I. Tayasu. Use of carbon and nitrogen isotope ratios in termite research. Ecol. Res., 13, 377-387 (1998).

[28] N. Senesi, T.M. Miano, G. Brunetti. Humic-like substances in organic amendments and effects on native soil humic substances. In Humic Substances in Terrestrial Ecosystems, pp. 531-593, Elsevier, Amsterdam (1996).

[29] F.J. Stevenson. Humic Substances Chemistry: Genesis, Composition and Reactions, 2nd ed., Wiley, New York (1994).

[30] M. Kakezawa, T. Nishida, Y. Takahara. Structural characteristics of humic acids extracted from woody composts by two-step composting process. Soil Sci. Plant Nutr., 38, 85-92 (1992).

[31] C. Garcia, T. Hernandez, F. Costa, J.C. Del Rio. Study of the lipidic and humic fractions from organic wastes before and after the composting process. Sci. Total Environ., 81/82, 551-560 (1989).

[32] D.P. Dick, P. Burba. Extraction kinetics and molecular size fractionation of humic substances from two Brazilian soils. J. Braz. Chem. Soc., 10, 146-152 (1999).

[33] K. Ghosh, M. Schnitzer. Ultraviolet-visible and visible absorption spectroscopic investigations in relation to macromolecular characteristics of humic substances. J. Soil Sci., 30, 735-754 (1979).

[34] M. De Nobili, G. Bragado, J.M. Alcaniz, A. Puigbo, L. Cornellas. Characterization of electrophoretic fractions of humic substances with different electrofocusing behavior. Soil Sci., 150, 763-770 (1990).

[35] J. Rodrigues, O. Faix, H. Pereira. Determination of lignin content of Eucalyptus glogulus wood using FTIR spectroscopy. Holzforschung, 52, 46-50 (1998).

[36] G. Barancikova, N. Senesi, G. Brunetti. Chemical and spectroscopic characterization of humic acids isolated from different Slovak soil types. Geoderma, 78, 251-266 (1997).

[37] G. Ait baddi, M. Hafidi, V. Gilard, J.-C. Revel. Characterization of humic acids produced during composting of olive mill wastes: elemental and spectroscopic analyses (FTIR and ${ }^{13}$ C-NMR). Agronomie, 23, 1-6 (2003).

[38] S.L. Lin, C.W. Dence. Methods in Lignin Chemistry, T.E. Timell (Ed.), State University of New York (1992).

[39] M. Kononova. Soil Organic Matter Its Nature, Its Role in Soil Formation and in Soil Fertility, Tome I, p. 182, Pergamon Press, London (1966).

[40] D.H. Gouge, K.A. Smith, C. Olson, P. Baker. Drywood Termites, The University of Arizona College of Agriculture and Life Sciences, Tucson, AZ (2001).

[41] N. Nguyen. Sustaining a microliter biosphere: Chemical composition of termite gut, CURJ, Caltech, USA, April, 32-36 (2002). 